\title{
MONOTONICITY OF RATIO BETWEEN THE GENERALIZED LOGARITHMIC MEANS
}

\author{
Feng QI, Shou-Xin Chen And ChaO-PIng Chen
}

Abstract. Let $c>b>a>0$ be real numbers. Then the function $f(r)=\frac{L_{r}(a, b)}{L_{r}(a, c)}$ is strictly decreasing on $(-\infty, \infty)$, where $L_{r}(a, b)$ denotes the generalized (extended) logarithmic mean of two positive numbers $a$ and $b$.

\section{Mathematics subject classification (2000): 26D15, 26E60.}

Key words and phrases: monotonicity, inequality, ratio, generalized logarithmic mean, extended logarithmic mean, identric mean, exponential mean.

\section{REFERENCES}

[1] H. Alzer, On an inequality of H. Minc and L. Sathre, J. Math. Anal. Appl., 179, (1993), 396-402.

[2] P. S. Bullen, A Dictionary of Inequalities, Pitman Monographs and Surveys in Pure and Applied Mathematics, 97, Addison Wesley Longman Limited, 1998.

[3] T. H. CHAN, P. GAO AND F. QI, On a generalization of Martins' inequality, Monatsh. Math., 138, (3) (2003), 179-187. RGMIA Res. Rep. Coll., 4, (1) (2001), Art. 12, 93-101; Available online at URL: http: //rgmia.vu.edu.au/v4n1.html.

[4] CH.-P. CHEN, F. QI, Notes on proofs of Alzer's inequality, Octogon Math. Mag., 11, (1) (2003), $29-33$.

[5] Ch.-P. Chen, F. QI, P. CEROne AND S. S. Dragomir, Monotonicity of sequences involving convex and concave functions, Math. Inequal. Appl., 6, (2) (2003), 229-239. RGMIA Res. Rep. Coll., 5, (1) (2002), Art. 1, 3-13; Available online at URL: http://rgmia.vu.edu.au/v5n1.html.

[6] N. Elezović, J. PeČArić, On Alzer's inequality, J. Math. Anal. Appl., 223, (1998), 366-369.

[7] B.-N. GuO, F. QI, An algebraic inequality, II, RGMIA Res. Rep. Coll., 4, (1) (2001), Art. 8, 55-61; Available online at URL: http://rgmia.vu.edu.au/v4n1.html.

[8] B.-N. GuO, F. QI, Inequalities and monotonicity of the ratio for the geometric means of a positive arithmetic sequence with arbitrary difference, Tamkang. J. Math., 34, (3) (2003), 261-270.

[9] B.-N. GuO, F. QI, Monotonicity of sequences involving geometric means of positive sequences with monotonicity and logarithmical convexity, Math. Inequal. Appl., 9, (1) (2006), 1-9.

[10] J.-CH. KuANG, Chángyòng Bùděngshì (Applied Inequalities), 2nd ed., Hunan Education Press, Changsha, China, 1993. (Chinese)

[11] J.-CH. KuAng, Some extensions and refinements of Minc-Sathre inequality, Math. Gaz., 83, (1999), 123-127.

[12] ZH. LiU, New generalization of H. Alzer's inequality, Tamkang J. Math., 34, (3) (2003), 255-260.

[13] J. S. MARTINS, Arithmetic and geometric means, an applications to Lorentz sequence spaces, Math Nachr., 139, (1988), 281-288.

[14] H. Minc, L. Sathre, Some inequalities involving $(r !)^{1 / r}$, Proc. Edinburgh Math. Soc., 14, (1964/65), 41-46.

[15] D. S. Mitrinović, Analytic Inequalities, Springer-Verlag, Berlin, 1970.

[16] N. OzEKI, On some inequalities, J. College Arts Sci. Chiba Univ., 4, (3) (1965), 211-214. (Japanese) 
[17] F. QI, An algebraic inequality, J. Inequal. Pure Appl. Math., 2, (1) (2001), Art. 13; Available online at URL: http://jipam.vu.edu.au/article.php?sid=129. RGMIA Res. Rep. Coll., 2, (1) (1999), Art. 8, 81-83; Available online at URL: http://rgmia.vu.edu .au/v2n1.html.

[18] F. QI, Generalizations of Alzer's and Kuang's inequality, Tamkang J. Math., 31, (3) (2000), 223-227. RGMIA Res. Rep. Coll., 2, (6) (1999), Art. 12, 891-895; Available online at URL: http://rgmia.vu.edu.au/v2n6.html.

[19] F. QI, Generalization of H. Alzer's inequality, J. Math. Anal. Appl., 240, (1999), 294-297.

[20] F. QI, Inequalities and monotonicity of sequences involving $\sqrt[n]{(n+k) ! / k !}$, Soochow J. Math., 29, (4) (2004), 353-361. RGMIA Res. Rep. Coll., 2, (5) (1999), Art. 8, 685-692; Available online at URL: http://rgmia.vu.edu.au/v2n5.html.

[21] F. QI, Inequalities and monotonicity of the ratio for the geometric means of a positive arithmetic sequence with unit difference, Austral. Math. Soc. Gaz., 30, (3) (2003), 142-147. Internat. J. Math. Ed. Sci. Tech., 34, (4) (2003), 601-607. RGMIA Res. Rep. Coll., 6, (2003), suppl., Art. 2; Available online at $U R L:$ http://rgmia.vu.edu. au/v6 (E) .html.

[22] F. QI, On a new generalization of Martins' inequality, RGMIA Res. Rep. Coll., 5, (3) (2002), Art. 13, 527-538; Available online at URL: http: //rgmia.vu.edu.au/v5n3.html.

[23] F. QI, CH.-P. CHEN, Monotonicity and inequalities for ratio of the generalized logarithmic means, RGMIA Res. Rep. Coll., 6, (2) (2003), Art. 18, 333-339; Available online at URL: http://rgmia.vu.edu.au/v6n2.html.

[24] F. QI, L. DeBnATH, On a new generalization of Alzer's inequality, Internat. J. Math. Math. Sci., 23, (12) (2000), 815-818.

[25] F. QI, B.-N. GuO, An inequality between ratio of the extended logarithmic means and ratio of the exponential means, Taiwanese J. Math., 7, (2) (2003), 229-237. RGMIA Res. Rep. Coll., 4, (1) (2001), Art. 8, 55-61; Available online at $U R L$ : http://rgmia.vu .edu.au/v4n1.html.

[26] F. QI, B.-N. GuO, Monotonicity of sequences involving convex function and sequence, Math. Inequal. Appl. 9, (2) (2006), 247-254. RGMIA Res. Rep. Coll., 3, (2) (2000), Art. 14, 321-329; Available online at URL: http://rgmia.vu . edu . au/v3n2 .html.

[27] F. QI, B.-N. GUO, Monotonicity of sequences involving geometric means of positive sequences with logarithmical convexity, RGMIA Res. Rep. Coll., 5, (3) (2002), Art. 10, 497-507; Available online at URL: http://rgmia.vu.edu.au/v5n3.html.

[28] F. QI, B.-N. GuO, Some inequalities involving the geometric mean of natural numbers and the ratio of gamma functions, RGMIA Res. Rep. Coll., 4, (1) (2001), Art. 6, 41-48; Available online at URL: http://rgmia.vu.edu.au/v4n1.html.

[29] F. QI, B.-N. GUO AND L. DEBNATH, A lower bound for ratio of power means, Internat. J. Math. Math. Sci., 2004, (1) (2004), 49-53. RGMIA Res. Rep. Coll., 5, (4) (2002), Art. 2; Available online at URL: http://rgmia.vu.edu.au/v5n4.html.

[30] F. QI, Q.-M. LuO, Generalization of H. Minc and J. Sathre's inequality, Tamkang J. Math., 31, (2) (2000), 145-148. RGMIA Res. Rep. Coll., 2, (6) (1999), Art. 14, 909-912; Available online at URL: http://rgmia.vu.edu.au/v2n6.html.

[31] F. QI, N. TowGHI, Inequalities for the ratios of the mean values of functions, Nonlinear Funct. Anal. Appl., 9, (1) (2004), 15-23. An inequality for the ratios of the arithmetic means of functions with a positive parameter, RGMIA Res. Rep. Coll., 4, (2) (2001), Art. 15, 305-309; Available online at URL: http://rgmia.vu.edu.au/v4n2.html.

[32] J. A. SAmpaio Martins, Inequalities of Rado-Popoviciu type, In: Marques de Sá, Eduardo (ed.) et al. Mathematical studies. Homage to Professor Doctor Luís de Albuquerque. Coimbra: Universidade de Coimbra, Faculdade de Ciências e Tecnologia, Departamento de Matemática, (1994), 169-175.

[33] J. SÁNDOR, Comments on an inequality for the sum of powers of positive numbers, RGMIA Res. Rep. Coll., 2, (2) (1999), 259-261; Available online at URL: http://rgmia.vu . edu . au/v2n2 .html.

[34] J. SÁNDOR, On an inequality of Alzer, J. Math. Anal. Appl., 192, (1995), 1034-1035.

[35] J. SÁNDOR, On an inequality of Bennett, General Mathematics (Sibiu), 3, (3-4) (1995), 121-125.

[36] K. B. Stolarsky, Generalizations of the logarithmic mean, Math. Mag., 48, (1975), 87-92.

[37] K. B. Stolarsky, The power and generalized logarithmic means, Amer. Math. Monthly, 87, (1980), 545-548.

[38] J. S. UME, An elementary proof of H. Alzer's inequality, Math. Japon., 44, (3) (1996), 521-522.

[39] M.-J. WANG, B. Hu, A poof of monotonicity of H. Alzer's function and some properties, Shùxué de Shíjiàn yǔ Rènshí (Mathematics in Theory and Practice), 36, (10) (2006), 243-246. (Chinese) 
[40] Z.-K. Xu, On further generalization of an inequality of H. Alzer, J. Zhējiang Shifàn Dàxué Xuébào Zìrăn Kēxué Băn (J. Zhejiang Norm. Univ. (Nat. Sci.)), 25, (3) (2002), 217-220. (Chinese)

[41] Z.-K. XU, D.-P. XU, A general form of Alzer's inequality, Comput. Math. Appl., 44, (3-4) (2002), 365-373. 